\title{
Assessing Potential Climate Change Impacts on Irrigation Requirements of Major Crops in the Brazos Headwaters Basin, Texas
}

\author{
Ripendra Awal ${ }^{1, *(\mathbb{D}}$, Ali Fares ${ }^{2} \mathbb{D}$ and Haimanote Bayabil ${ }^{3}$ \\ 1 College of Agriculture and Human Sciences, Prairie View A\&M University, Prairie View, TX 77446, USA \\ 2 Office of Research, Innovation and Sponsored Programs, Prairie View A\&M \\ University, Prairie View, TX 77446, USA; alfares@pvamu.edu \\ 3 Agricultural and Biological Engineering, Tropical Research and Education Center, Institute of Food and \\ Agricultural Sciences, University of Florida, Homestead, FL 33031, USA; hbayabil@ufl.edu \\ * Correspondence: riawal@pvamu.edu; Tel.: +1-936-261-5092
}

Received: 14 October 2018; Accepted: 5 November 2018; Published: 9 November 2018

check for updates

\begin{abstract}
In order for the agricultural sector to be sustainable, farming practices and management strategies need to be informed by site-specific information regarding potential climate change impacts on irrigation requirements and water budget components of different crops. Such information would allow managers and producers to select cropping systems that ensure efficient use of water resources and crop productivity. The major challenge in understanding the link between cropping systems and climate change is the uncertainty of how the climate would change in the future and lack of understanding how different crops would respond to those changes. This study analyzed the potential impact of climate change on irrigation requirements of four major crops (cotton, corn, sorghum, and winter wheat) in the Brazos Headwaters Basin, Texas. The irrigation requirement of crops was calculated for the baseline period (1980-2010) and three projected periods: 2020s (2011-2030), 2055s (2046-2065), and 2090s (2080-2099). Daily climate predictions from 15 general circulation models (GCMs) under three greenhouse gas (GHG) emission scenarios (B1, A1B, and A2) were generated for three future periods using the Long Ashton Research Station-Weather Generator (LARS-WG) statistical downscaling model. Grid-based (55 grids at $\sim 38 \mathrm{~km}$ resolution) irrigation water requirements (IRRs) and other water budget components of each crop were calculated using the Irrigation Management System (IManSys) model. Future period projection results show that evapotranspiration (ET) and IRR will increase for all crops, while precipitation is projected to decrease compared with the baseline period. On average, precipitation meets only $25-32 \%$ of the ET demand, depending on crop type. In general, projections from almost all GCMs show an increase in IRR for all crops for the three future periods under the three GHG emission scenarios. Irrigation requirement prediction uncertainty between GCMs was consistently greater in July and August for corn, cotton, and sorghum regardless of period and emission scenario. However, for winter wheat, greater uncertainties between GCMs were observed during April and May. Irrigation requirements show significant variations across spatial locations. There was no consistent spatial trend in changes of IRR for the four crops. A unit change in precipitation is projected to affect IRR differently depending on the crop type.
\end{abstract}

Keywords: irrigation requirement; climate change; IManSys; Brazos Headwaters Basin 


\section{Introduction}

Climate change is a serious threat to all aspects of human lives as it impacts major sectors such as energy and agricultural production, which strongly depend on water availability [1-5]. An increase in temperature and a decrease in precipitation are often reported as the main features of climate change $[3,6,7]$. These changes are even more pronounced in arid and semiarid regions, e.g., western and central plain regions of the U.S. [4], including west and northwest Texas, which are expected to experience more severe and frequent water shortages. As a result, water management practices must address critical water shortage and competing needs in arid and semiarid regions in a sustainable way [1,4].

The Brazos River Basin (BRB) is one of the major river basins in Texas. The river and its tributaries start in the west part of the state and gain momentum as the river heads southeast to the Gulf of Mexico. The river serves as a water source for homes and businesses across the state for domestic, agricultural, and industrial uses [8]. In addition, the river offers important recreational opportunities along its path, e.g., boating, swimming, and fishing [9]. As a major water user in the BRB and globally, the agricultural sector is expected to develop water management strategies that would minimize the impacts of water shortage on crop production [4]. While some reports suggest an increase in the acreage of irrigated agriculture to meet the increasing food demand due to population pressure [10], there are also concerns that expansion of irrigated areas would exacerbate an already dwindling freshwater resource [4]. Blanc et al. [4] reported expected water shortages due to increased water demands would result in a reduction in crop yields especially in the southwestern parts of the U.S. The authors further argued that irrigation agriculture would not be sustainable due to water shortages in such regions. Therefore, in order for the agricultural sector to be sustainable across the BRB, farming practices and management strategies have to be modified based on site-specific information regarding the potential impacts of climate change on irrigation water requirements and water budget components of different crops. Such information would allow managers and producers to select cropping systems that ensure efficient use of water resources and result in adequate crop productivity. The major challenge in understanding the links between cropping systems and climate change is the uncertainty of how the climate would change in the future and also the lack of understanding how different crops would respond to those changes.

In this regard, the use of general circulation models (GCMs) has been a useful tool to quantify future climate change scenarios under site-specific conditions $[1,3,11]$. Outputs from GCMs are then downscaled to specific locations or regions and used as inputs to crop growth and irrigation water allocation models to assess how irrigation water requirements and major water budget components would change under different cropping systems [5,12,13]. The Irrigation Management System (IManSys), a water allocation model, has been used to assess the impacts of potential future climate change scenarios on the irrigation water requirements of coffee and seed corn for Hawaii [13], and citrus for most of the major citrus producing region globally [5].

The main objective of this study was to assess the impacts of potential climate change on irrigation water requirements and the major water budget components, i.e., evapotranspiration, runoff, and drainage of four major row crops (cotton, corn, sorghum, and winter wheat) across the Brazos Headwaters Basin using the IManSys water allocation model and site-specific weather, soil, and crop data. 


\section{Materials and Methods}

\subsection{Study Area}

Brazos Headwaters Basin (Hydrologic Unit Code $=120,500$ ) is the upper sub-basin of Brazos River Basin (Figure 1a). It extends from Texas to New Mexico State covering an approximate area of $37,558 \mathrm{~km}^{2}$. Salt Fork Brazos and the Double Mountain Fork Brazos rivers are the major streams in the basin. The two streams are small ephemeral streams, which drain relatively large amounts of land but do not produce much streamflow [14]. About 73.5\% of the Brazos Headwaters Basin is covered by the Ogallala Aquifer, and a significant portion of irrigation water used in the basin is from groundwater. Depletion of groundwater is accelerating in this aquifer due to increases in the use of groundwater for agriculture, threatening the long-term sustainability of the agricultural sector of the region. Major agricultural crops grown in this basin include winter wheat, sorghum, corn, and cotton.

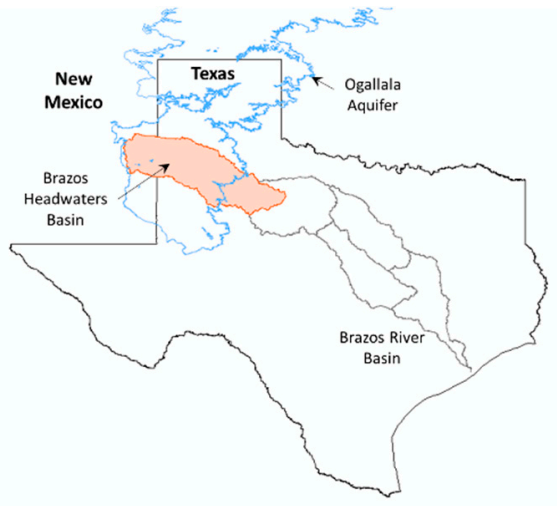

(a)

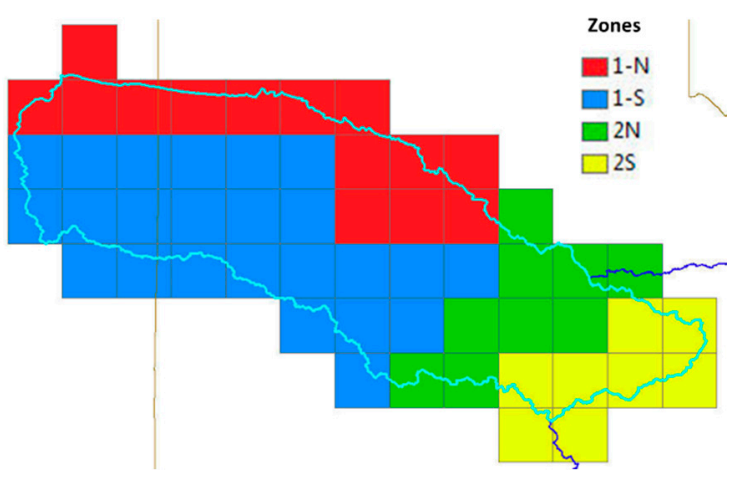

(b)

Figure 1. Map of the state of Texas with (a) location of the Brazos Headwaters Basin and (b) NCEP-CFSR grid cells and Texas Agricultural Statistical Districts (1-N, 1-S, 2-N, and 2-S) covering the Brazos Headwaters Basin.

\subsection{Data}

Gridded climate data: National Centers for Environmental Prediction (NCEP) Climate Forecast System Reanalysis (CFSR) daily grid data of precipitation, maximum and minimum temperature, and solar radiation (http: / / globalweather.tamu.edu/) from 1981 to 2010 (hereinafter baseline climate data) were used for downscaling of monthly GCMs projections, at 55 grid cells ( $\sim 38 \mathrm{~km}$ resolution) within the Brazos Headwaters Basin (Figure 1b), using the Long Ashton Research Station-Weather Generator (LARS-WG)statistical downscaling model.

Projected climate data: The impact of climate change on irrigation water requirements (IRRs) and other soil water budget components for different crops were estimated for three periods (i.e., the 2020s, 2055s, and 2090s) using downscaled GCM projections. The climate data for three future periods, i.e., 2020s, 2055s, and 2090s, were generated using outputs from 15 GCMs (Table 1) under three greenhouse gas emission scenarios (B1-Low, A1B-Medium, and A2-High) using a statistical downscaling model, LARS-WG [15]. This study used projected climate data from our previous study and detailed information on analysis of future climate projection of 15 GCMs for the Brazos Headwaters Basin can be found in Awal et al. [3]. 
Table 1. Summary of selected general circulation models (GCMs) used in this study.

\begin{tabular}{|c|c|c|c|}
\hline GCMs & Centre and Country & Grid Resolution & Emission Scenarios \\
\hline BCM2.0 & Bjerknes Centre for Climate Research, Norway & $1.9^{\circ} \times 1.9^{\circ}$ & $\mathrm{A} 1 \mathrm{~B}$ and $\mathrm{B} 1$ \\
\hline CGCM3.1 & $\begin{array}{l}\text { Canadian Centre for Climate Modelling and } \\
\text { Analysis, Canada }\end{array}$ & $1.9^{\circ} \times 1.9^{\circ}$ & A1B \\
\hline CNRM-CM3 & $\begin{array}{l}\text { Centre National de Recherches } \\
\text { Meteorologiques, France }\end{array}$ & $1.9^{\circ} \times 1.9^{\circ}$ & $\mathrm{A} 1 \mathrm{~B}$ and $\mathrm{A} 2$ \\
\hline CSIRO-MK3.0 & $\begin{array}{l}\text { Australia's Commonwealth Scientific and } \\
\text { Industrial Research Organisation, Australia }\end{array}$ & $1.9^{\circ} \times 1.9^{\circ}$ & $\mathrm{A} 1 \mathrm{~B}$ and $\mathrm{B} 1$ \\
\hline FGOALS-g1.0 & Institute of Atmospheric Physics, China & $2.8^{\circ} \times 2.8^{\circ}$ & $\mathrm{A} 1 \mathrm{~B}$ and $\mathrm{B} 1$ \\
\hline GFDL-CM2.1 & Geophysical Fluid Dynamics Laboratory, USA & $2.0^{\circ} \times 2.5^{\circ}$ & $\mathrm{A} 1 \mathrm{~B}, \mathrm{~A} 2$, and $\mathrm{B} 1$ \\
\hline GISS-AOM & Goddard Institute for Space Studies, USA & $3^{\circ} \times 4^{\circ}$ & $\mathrm{A} 1 \mathrm{~B}$ and $\mathrm{B} 1$ \\
\hline HadCM3 & UK Met Office, UK & $2.5^{\circ} \times 3.75^{\circ}$ & $\mathrm{A} 1 \mathrm{~B}, \mathrm{~A} 2$, and $\mathrm{B} 1$ \\
\hline HadGEM1* & UK Met Office, UK & $1.3^{\circ} \times 1.9^{\circ}$ & $\mathrm{A} 1 \mathrm{~B}$ and $\mathrm{A} 2$ \\
\hline INM-CM3.0 & Institute for Numerical Mathematics, Russia & $4^{\circ} \times 5^{\circ}$ & $\mathrm{A} 1 \mathrm{~B}, \mathrm{~A} 2$, and $\mathrm{B} 1$ \\
\hline IPSL-CM4 & Institute Pierre Simon Laplace, France & $2.5^{\circ} \times 3.75^{\circ}$ & $\mathrm{A} 1 \mathrm{~B}, \mathrm{~A} 2$, and $\mathrm{B} 1$ \\
\hline MRI-CGCM2.3.2 & Meteorological Research Institute, Japan & $2.8^{\circ} \times 2.8^{\circ}$ & $\mathrm{A} 1 \mathrm{~B}$ and $\mathrm{B} 1$ \\
\hline ECHAM5-OM & Max-Planck Institute for Meteorology, Germany & $1.9^{\circ} \times 1.9^{\circ}$ & $\mathrm{A} 1 \mathrm{~B}, \mathrm{~A} 2$, and $\mathrm{B} 1$ \\
\hline CCSM3 & National Centre for Atmospheric Research, USA & $1.4^{\circ} \times 1.4^{\circ}$ & $\mathrm{A} 1 \mathrm{~B}, \mathrm{~A} 2$, and $\mathrm{B} 1$ \\
\hline $\mathrm{PCM}^{*}$ & National Centre for Atmospheric Research, USA & $2.8^{\circ} \times 2.8^{\circ}$ & $\mathrm{A} 1 \mathrm{~B}$ and $\mathrm{A} 2$ \\
\hline
\end{tabular}

Soil data: The soil hydrologic parameters of the major soil types of each grid cell were extracted from the United States Department of Agriculture, Natural Resources Conservation Service, Soil Survey Geographic Database (SSURGO). The extracted soil data include soil texture, the soil horizons, and the depth of each one of them and their corresponding minimum and maximum available water content, soil hydrologic group, and the depth of the water table.

Crop data: Cotton, winter wheat, corn, and sorghum are among the major crops grown in the Brazos Headwaters Basin (Figure 2a). The historical changes in the acreage of these crops are shown in Figure $2 \mathrm{~b}$. Cotton had the highest acreage while sorghum had the lowest acreage in 2011 during the last decade (2008-2017).

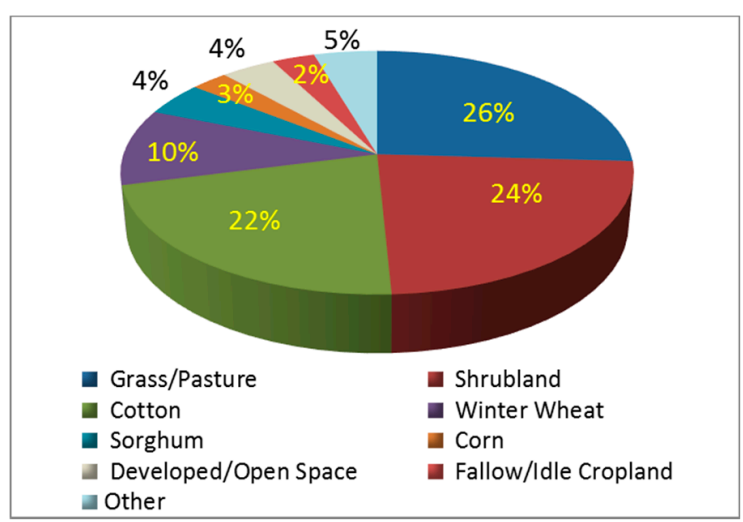

(a)

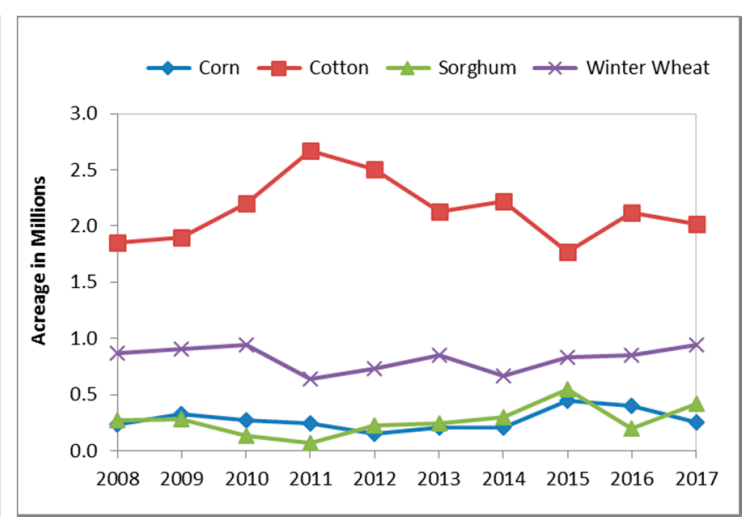

(b)

Figure 2. Major agricultural crops in Brazos Headwaters Basin. (a) Major land cover (2017). (b) Acreage of major croplands (2008-2017). 
Crop coefficients $(\mathrm{Kc})$ were selected based on the works of Howell et al. [16] and Allen et al. [17]. Planting and harvesting dates and the growing season of each crop were selected according to the geographic location of the simulated area (Table 2).

Table 2. Growing season timeline of corn, cotton, sorghum grain, and winter wheat crops [18].

\begin{tabular}{|c|c|c|c|c|c|c|}
\hline \multirow{2}{*}{ Crops } & \multirow{2}{*}{ Growing Season } & \multicolumn{4}{|c|}{ Zones (See Figure 1) } & \multirow{2}{*}{$\mathbf{L A I}_{\max }$} \\
\hline & & $1-\mathrm{N}$ & $1-S$ & $2-\mathrm{N}$ & $2-S$ & \\
\hline \multirow{3}{*}{ Corn, Field } & Planting Date & 20 April & 15 April & 22 April & 27 April & \multirow{3}{*}{5.71} \\
\hline & Harvesting Date & 30 September & 18 September & 9 September & 7 September & \\
\hline & Growing Season (Days) & 163 & 156 & 140 & 133 & \\
\hline \multirow{3}{*}{ Cotton } & Planting Date & 14 May & 10 May & 1 June & 25 May & \multirow{3}{*}{4.01} \\
\hline & Harvesting Date & 25 October & 21 October & 7 November & 7 November & \\
\hline & Growing Season (Days) & 164 & 164 & 159 & 166 & \\
\hline \multirow{3}{*}{$\begin{array}{l}\text { Sorghum, } \\
\text { Grain }\end{array}$} & Planting Date & 7 June & 29 May & 2 June & 7 May & \multirow{3}{*}{5.3} \\
\hline & Harvesting Date & 31 October & 25 October & 30 October & 14 October & \\
\hline & Growing Season (Days) & 146 & 149 & 150 & 160 & \\
\hline \multirow{3}{*}{$\begin{array}{l}\text { Winter } \\
\text { Wheat }\end{array}$} & Planting Date & 22 September & 27 September & 2 October & 6 October & \multirow{3}{*}{7.07} \\
\hline & Harvesting Date & 27 June & 25 June & 19 June & 19 June & \\
\hline & Growing Season (Days) & 278 & 271 & 260 & 256 & \\
\hline
\end{tabular}

Note: 1-N: Northern High Plains, 1-S: Southern High Plains, 2N: Northern Low Plains, and 2S: Southern Low Plains, $\mathrm{LAI}_{\max }$ : Maximum Leaf Area Index.

\subsection{Irrigation Management System (IManSys) Model}

The IManSys model [19] calculates daily irrigation requirements using daily historical climate data (rain and reference evapotranspiration), and site and crop-specific information (e.g., plant growth and soil parameters, and irrigation system). In addition to IRRs, IManSys also calculates runoff, drainage, rainfall canopy interception, and effective rainfall. More details on the IManSys model can be found in Fares and Fares [19], Fares et al. [5], and Fares et al. [13].

\subsection{Methods}

Figure 3 shows the framework of assessing the potential impact on irrigation water requirement of crops under different climate change scenarios. The NCEP-CFSR daily grid data of precipitation, maximum and minimum temperatures, and solar radiation were used as input to the LARS-WG model. Future climate projections were generated for three time periods (2011-2030, 2046-2065, and 2081-2099) and three emission scenarios (A1B, A2, and B1). The daily time series outputs of precipitation and evapotranspiration were used as inputs for the IManSys model. Other inputs required for IManSys include soil hydrologic parameters of the major soil type at each grid cell, SCS curve number, and different crop specific parameters ( $\mathrm{LAI}_{\max }, \mathrm{Kc}$, allowable soil water depletion, initial and final root depths). We used multiple sprinkler (Irrigation efficiency $=0.75$ ) irrigation system for all crops. The IManSys calculated irrigation water requirements and other water budget components (runoff, drainage, canopy interception, and effective rainfall) during baseline and three future periods (2020s, 2055s, and 2090s) under projected emission scenarios in all 55 grid cells covering the Upper Brazos Headwaters Basin. 


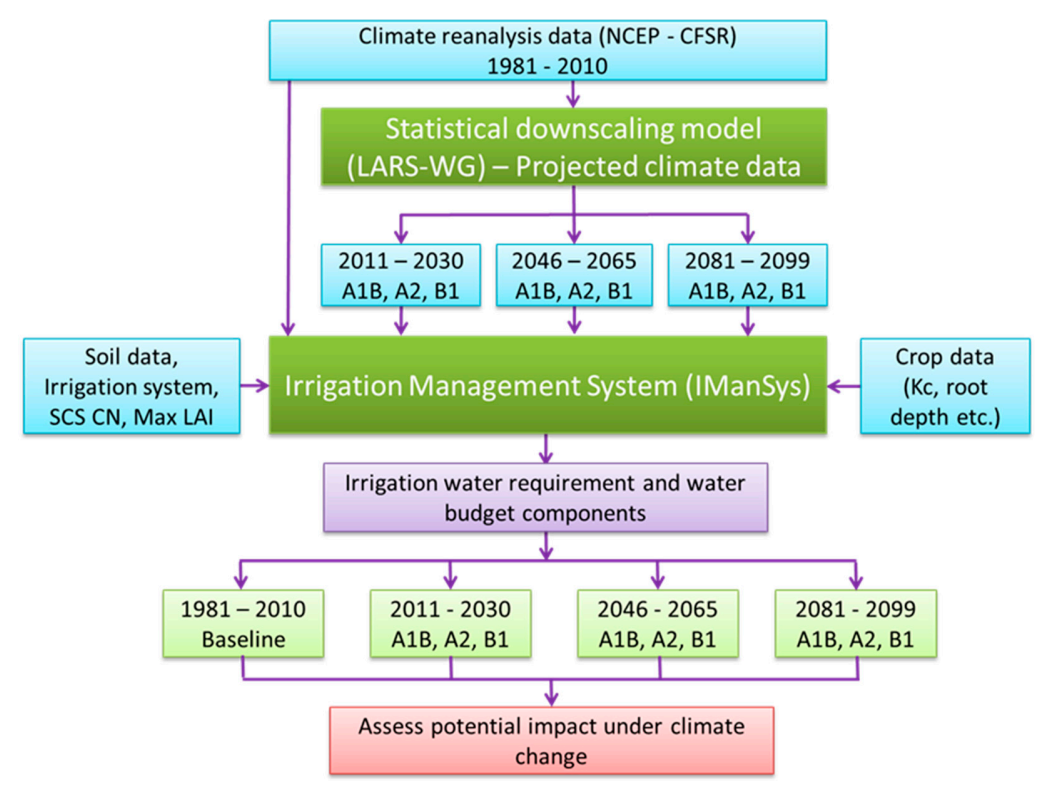

Figure 3. Framework for assessing the potential climate change impacts on irrigation requirements of crops.

\section{Results and Discussions}

\subsection{Water Budget Components under Different Crops}

Table 3 shows the summary of major water budget components for the four crops (corn, cotton, sorghum, and winter wheat) studied. The results are averaged across 55 grid cells for the baseline period. Overall, evapotranspiration dominates the water budget in the Brazos Headwaters Basin. Precipitation, on average, meets only $25-32 \%$ of the evapotranspiration demand, depending on crop type (Table 3). Drainage water losses were relatively small compared with the other water budget components; however, drainage from winter wheat was six-fold greater than from that of the other crops. The magnitude of runoff was very similar for the four crops. Results of this study are well within the values of other studies $[5,20]$ that report the dominance of evapotranspiration under arid and semi-arid climates. The north and west parts of Texas, including Brazos Headwaters Basin, receive a small amount of rainfall, and irrigation is critical to supplement the moisture deficit. Several studies have projected that climate change will pose a greater threat to people and agricultural practices in dry areas due to the marginal and scarcely available water resources [20-22].

Table 3. Summary of major water budget components for the baseline period.

\begin{tabular}{ccccccc}
\hline \multirow{2}{*}{ Crop } & GRAIN & IRR & ET & INT & RO & DR \\
\cline { 2 - 7 } & \multicolumn{7}{c}{$(\mathbf{m m})$} \\
\hline Corn & 209 & 802 & 841 & 32 & 12 & 0.1 \\
Cotton & 239 & 633 & 757 & 25 & 15 & 0.1 \\
Sorghum & 224 & 591 & 711 & 29 & 14 & 0.1 \\
Winter wheat & 263 & 736 & 829 & 32 & 13 & 0.6 \\
\hline
\end{tabular}

Note: GRAIN—Gross rainfall, IRR-irrigation requirement, ET-crop evapotranspiration, INT-interception, $\mathrm{RO}$-runoff, and DR—drainage.

Projected changes in the major water budget components with respect to their level during the baseline period show that evapotranspiration and irrigation requirement are expected to increase for all crops, while precipitation is projected to decrease (Figure 4). Detailed information about the projected changes in temperature and rainfall for the Brazos Headwaters Basin can be found in Awal et al. [3]. The projected increases in irrigation requirement were greater than the corresponding reductions 
in precipitation. Overall, projected changes in the water budget components compared with the baseline period are expected to be more pronounced towards the end of the 21st century (Figure 4). Greater changes are expected under the A2 (high) emission scenario compared to those under B1 (low) and AlB (medium) emission scenarios.

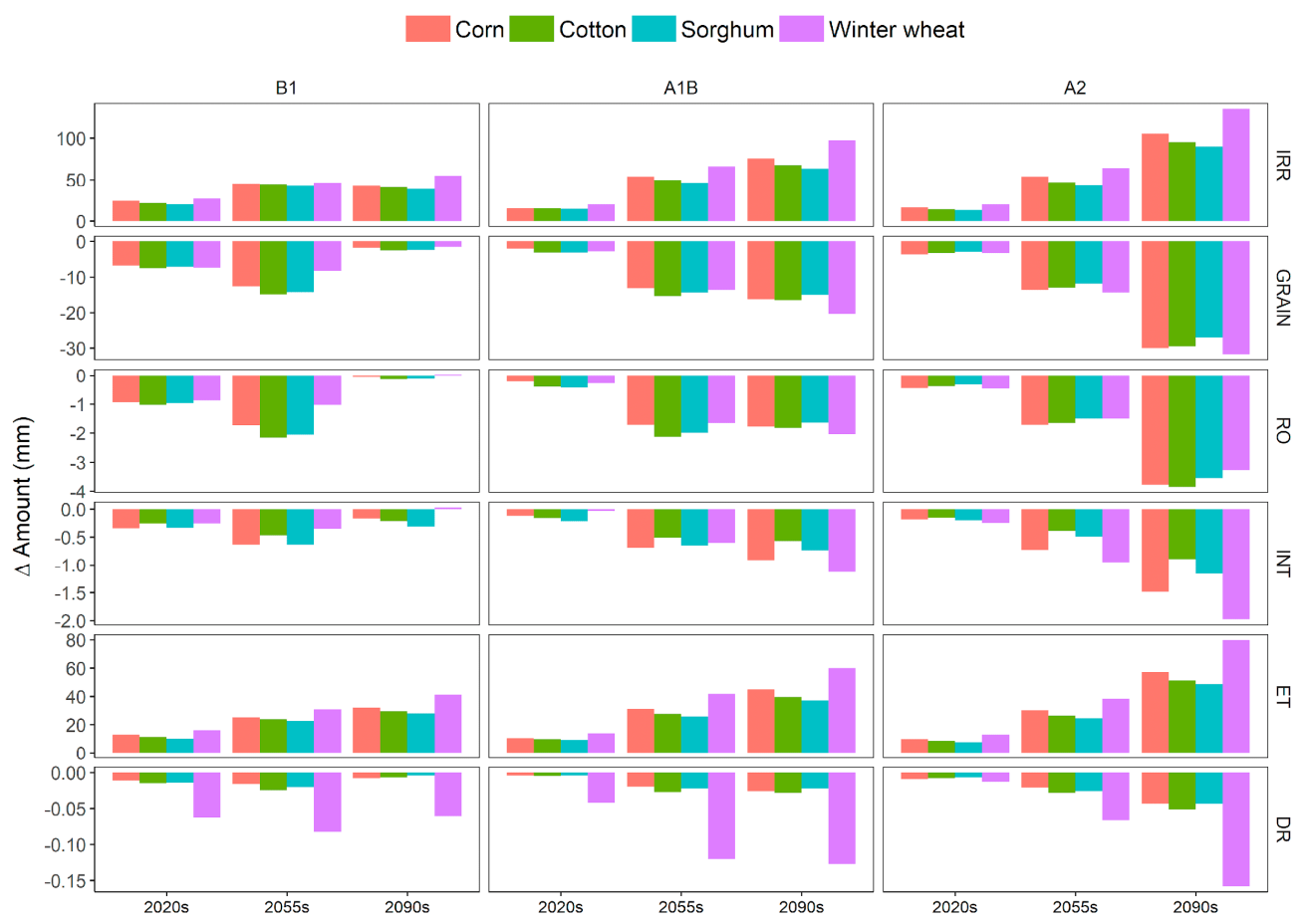

Figure 4. Projected changes in water budget components of different crops for three future periods under three greenhouse gas emissions scenarios. (Note: GRAIN—Gross Rainfall, IRR-Irrigation Requirement, ET-Crop Evapotranspiration, INT—Interception, RO—Runoff and DR-Drainage).

On the other hand, though drainage and canopy interception account only for a very small portion of the water budget, both variables are projected consistently to decrease for all crops during all future periods and under all greenhouse gas emission scenarios.

\subsection{Crop Irrigation Requirement Uncertainties between General Circulation Models}

In general, IRR for all crops for the three future periods under the three greenhouse gas emission scenarios are expected to increase based on almost all GCMs (Figure 5). Substantial differences in IRR are predicted between all emission scenarios during the 2090s period. However, there were few exceptions where some GCMs (e.g., CGCM3.1, HadCM3) predict a reduction in IRR during some months of the cropping seasons of some crops (Figure 5). For example, the CGMR model predicts a reduction in IRR during most of the cropping seasons of all crops except winter wheat (Figure 5) in the 2090s under the A1B (moderate) emission scenario. In this study, we estimated irrigation water requirement based on projected climate data (i.e., changes in temperature and precipitation) similar to other studies [23-25]. However, we did not consider the direct effects of increased $\mathrm{CO}_{2}$ concentrations on the joint physiological and structural effect on plant growth and related water savings during the growing period of crops. Thus, several studies which considered potential shortening of the growing seasons due to increase in growing season temperature and $\mathrm{CO}_{2}$ fertilization reported a decrease or only modest increase in irrigation water requirements for these crops in different regions of the United States [26,27]. Konzmann et al. [28] stated that increases of $>20 \%$ are projected with a low likelihood, for parts of Asia and North America; they further argued that if $\mathrm{CO}_{2}$ effects were ignored, however, global irrigation demand would remain constant, and increases would prevail globally except for Southern Asia where higher precipitation is projected. Döll [23] estimated that two-thirds of the global 
irrigated area would be significantly affected by increases in irrigation demand. Such increase in irrigation requirement coupled with dwindling available freshwater resources would necessitate to shifting agricultural fields to areas with reliable water sources or switch to crops with smaller water requirements [4], or conversion of heavily irrigation regions that are expected to be greatly affected by climate change to rainfed management [29].

a) Corn
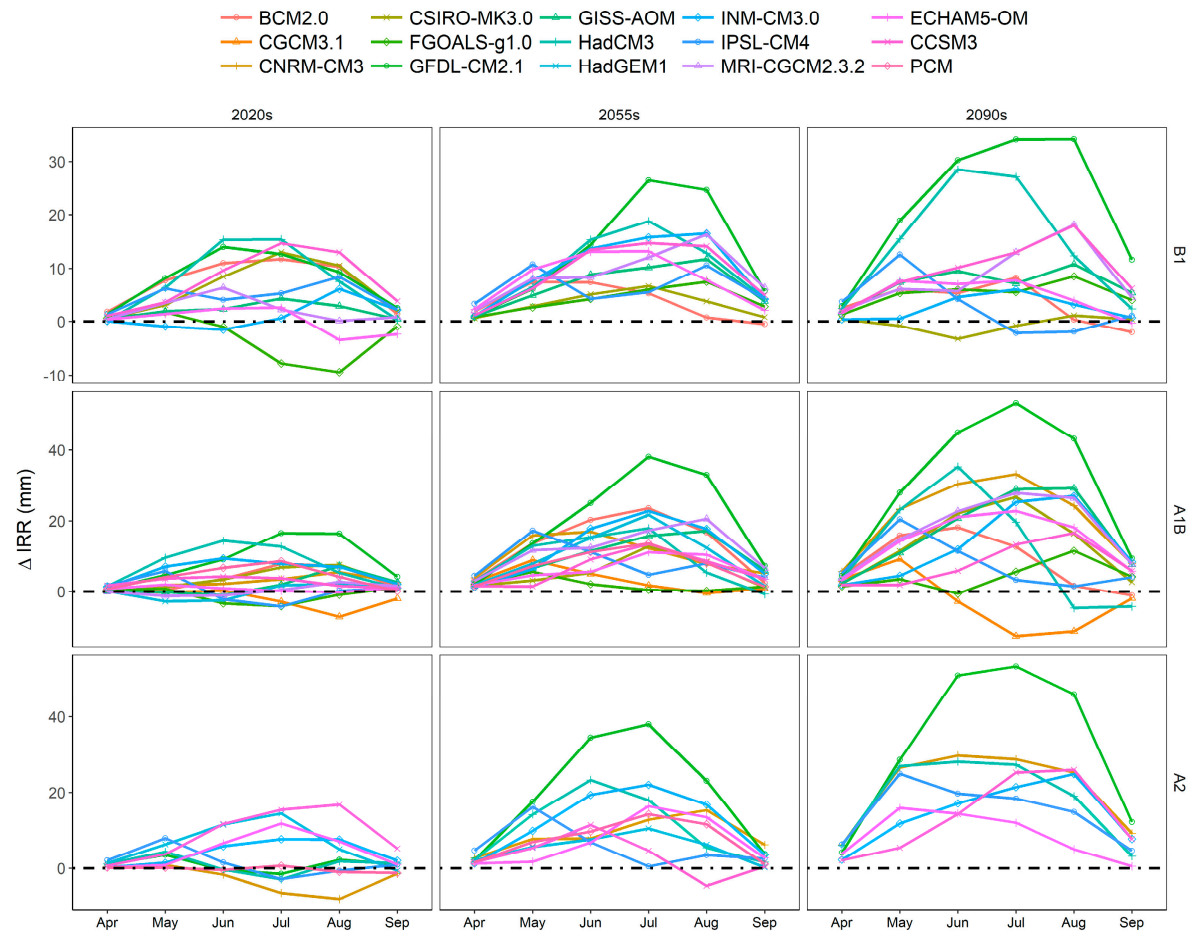

b) Cotton

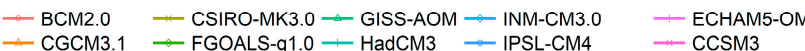

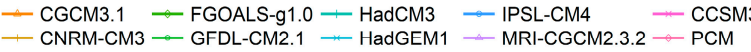

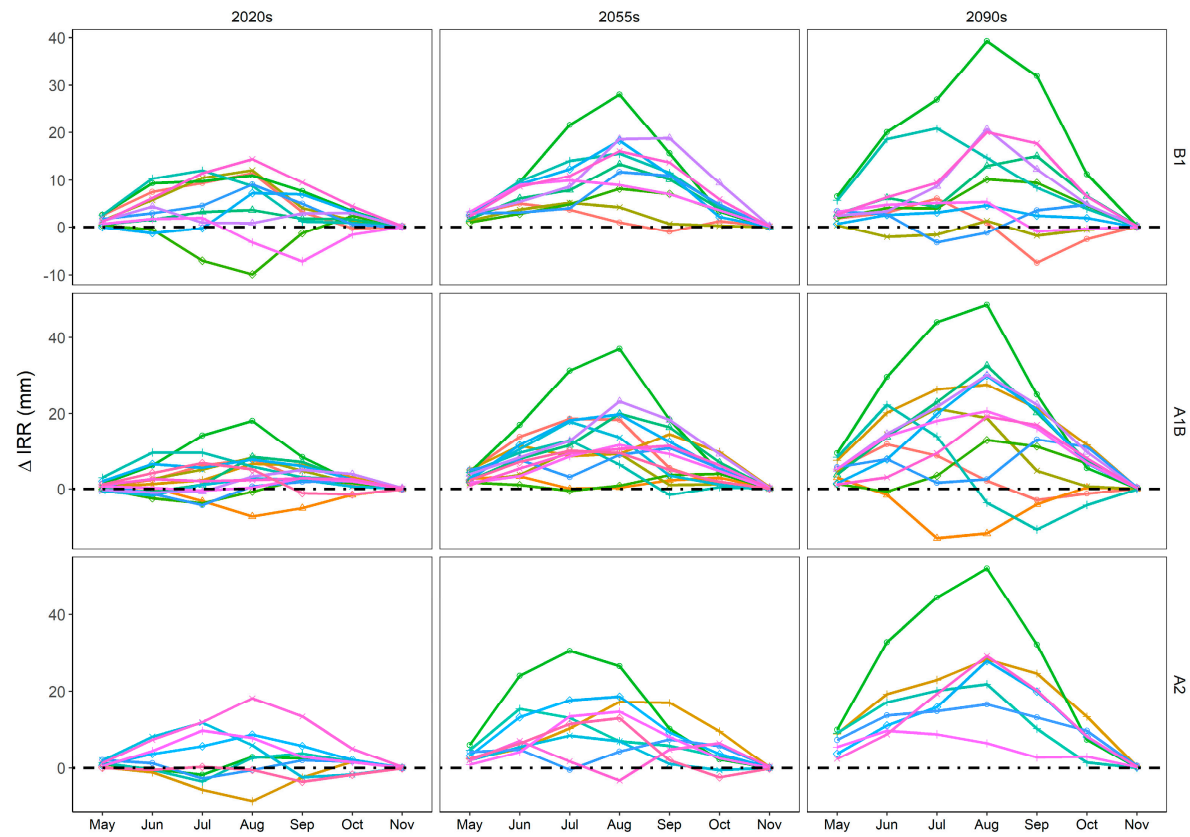

Figure 5. Cont. 
c) Sorghum

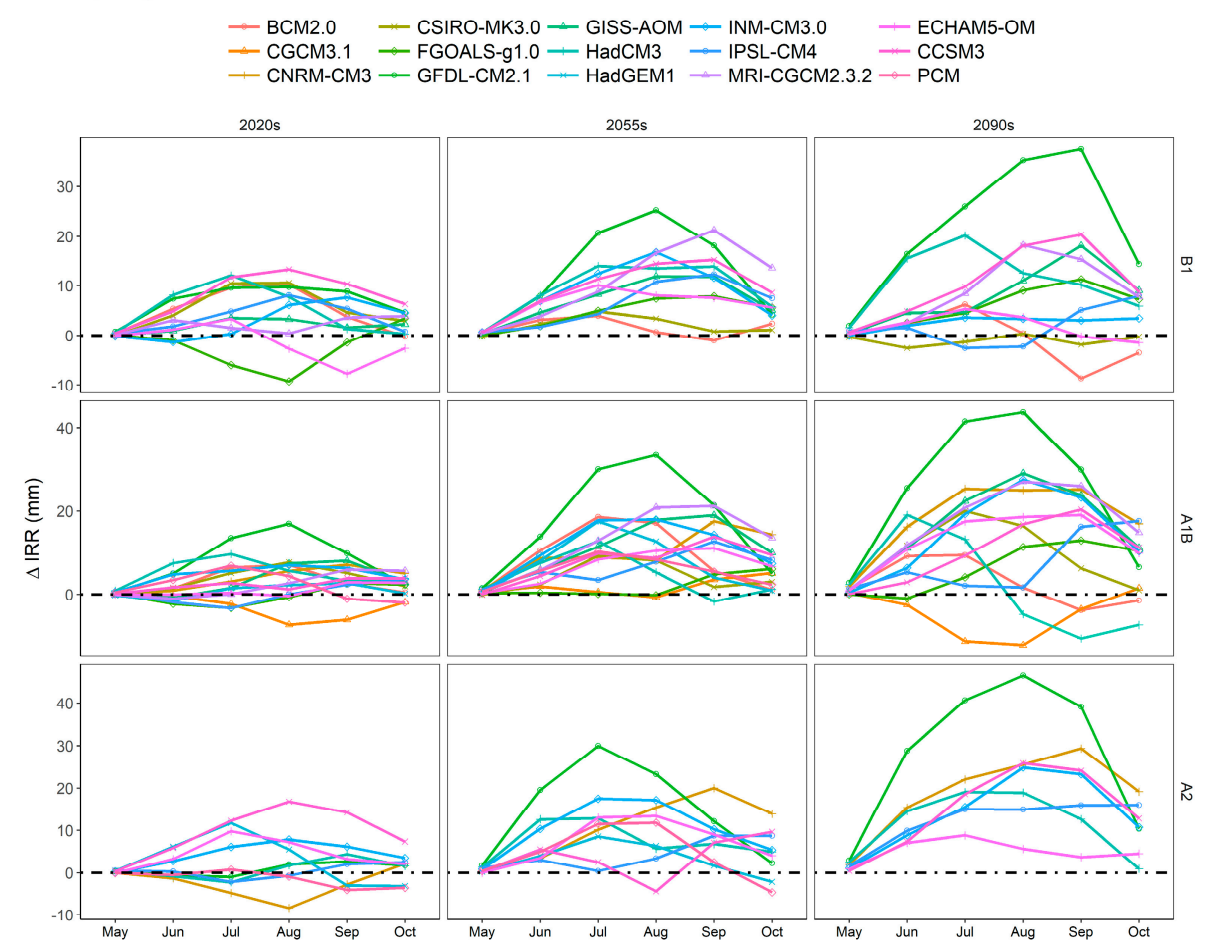

d) Winter wheat

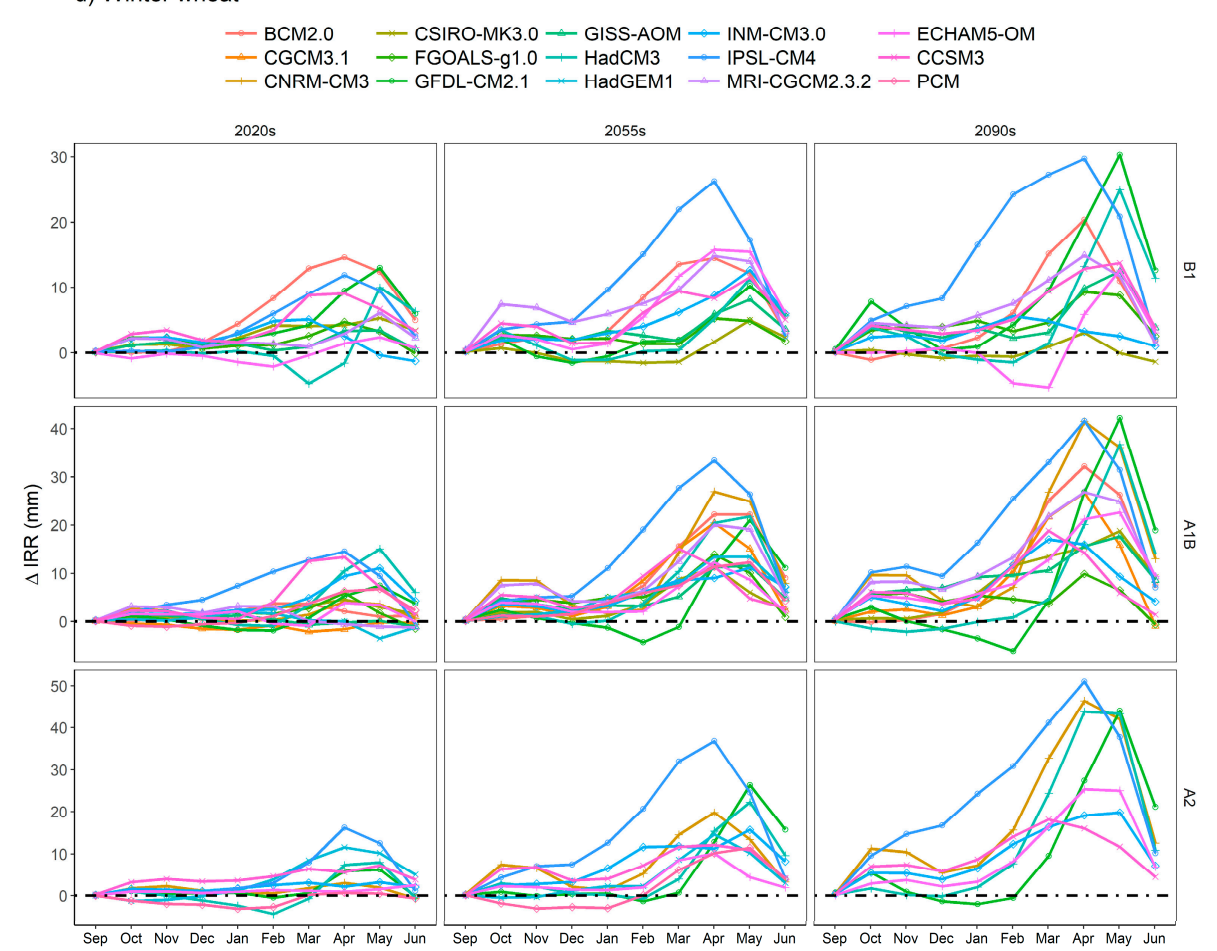

Figure 5. Uncertainties between GCMs in predicting monthly irrigation requirements of corn (a); cotton (b); sorghum (c); and winter wheat (d) for three future periods and under three greenhouse gas emission scenarios. 
On the other hand, the GFDL-CM2.1 model predictions are consistently greater than the other models during the 2055s and 2090s periods and under all three greenhouse gas emission scenarios. Irrigation requirement prediction variability between GCMs was consistently greater during July and August for corn, cotton, and sorghum regardless of future period and emission scenario. However, for winter wheat, greater variability between GCMs is projected during April and May (Figure 5d). Brumbelow and Georgakakos [30] reported that future changes in irrigation requirements will be affected by geographic locations in the U.S., where decreased irrigation requirements are projected for the Northern and Western U.S. while an increase in irrigation demand is projected for the Southern U.S. These authors also reported that winter wheat and corn in the Southern U.S. will not show yield increases. Overall, in GCMs predicted future temperature and precipitation translate into variabilities in irrigation water requirements of the four crops. Hopmans et al. [31] attributed uncertainties in the future water supply to uncertainties due to projected precipitation.

\subsection{Spatial Changes in Projected Irrigation Requirements}

Irrigation requirements show significant variations across spatial locations, and it is important to understand the spatial trends of changes in irrigation requirements of crops relative to the baseline period. Overall, IRR of all four crops is expected to increase throughout the Brazos Headwaters Basin under the three emission scenarios and three future periods, with few exceptions for sorghum and winter wheat, for which predicted increases in IRR were consistently smaller, and at times a reduction in IRR was predicted, under A2 (winter wheat) and A1B and A2 emission scenarios (sorghum) for the 2020s period (Figure 6). This was unexpected given the fact that the A2 scenario represents the highest $\mathrm{CO}_{2}$ emission of the three scenarios. Substantial increases in IRR were predicted during the 2090s period under the A2 (high) emission scenario for all crops.

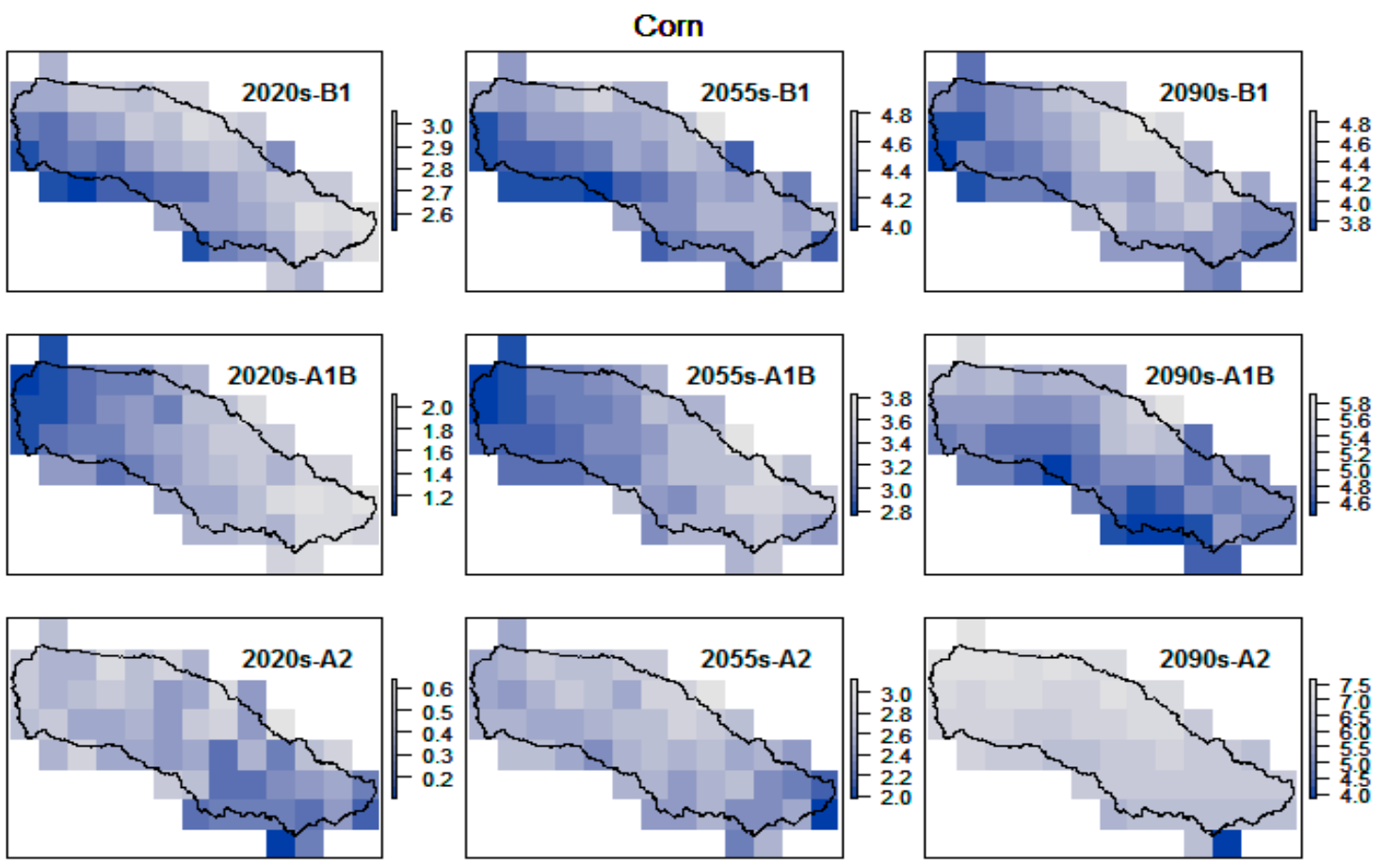

(a)

Figure 6. Cont. 


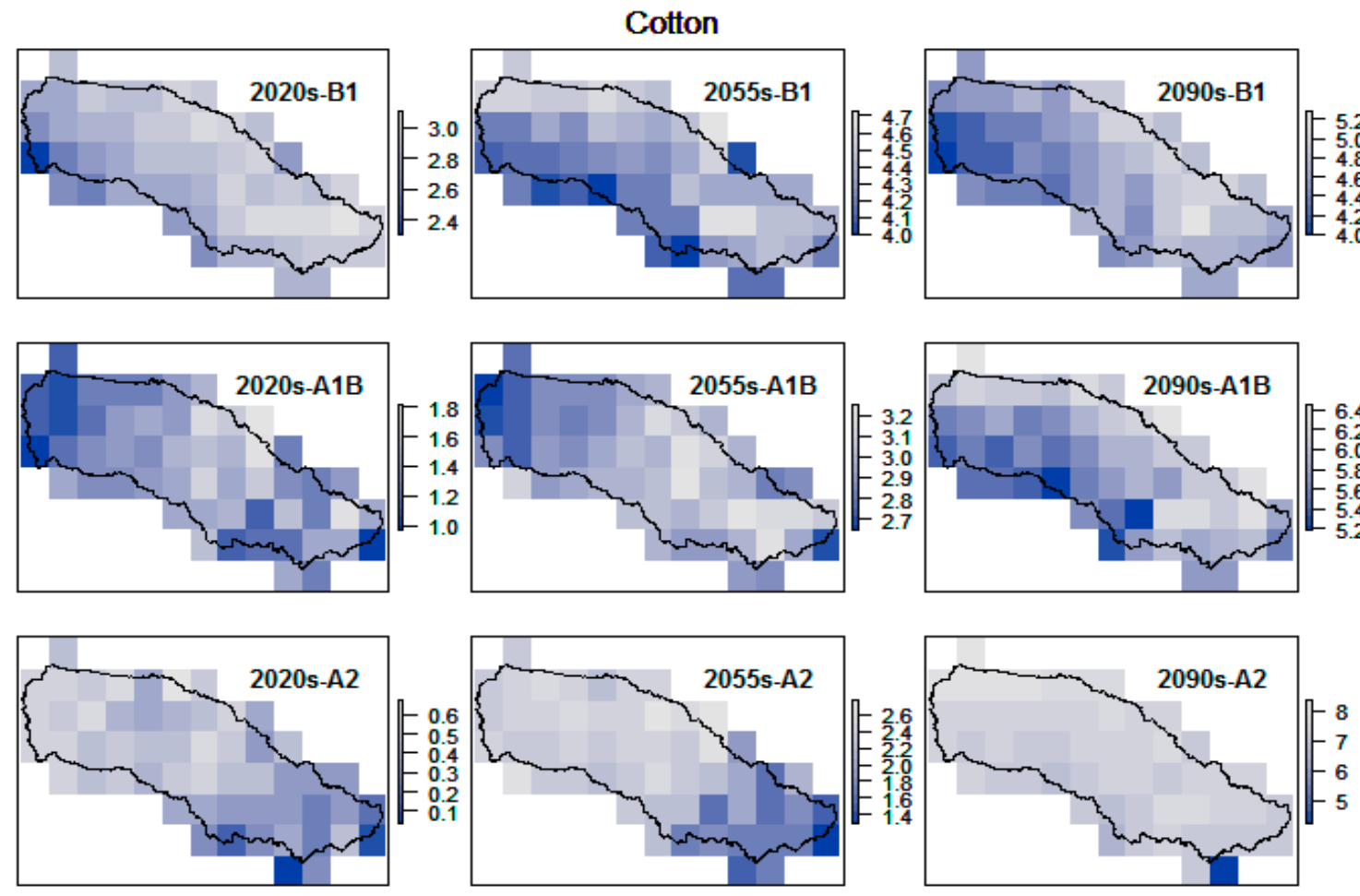

(b)
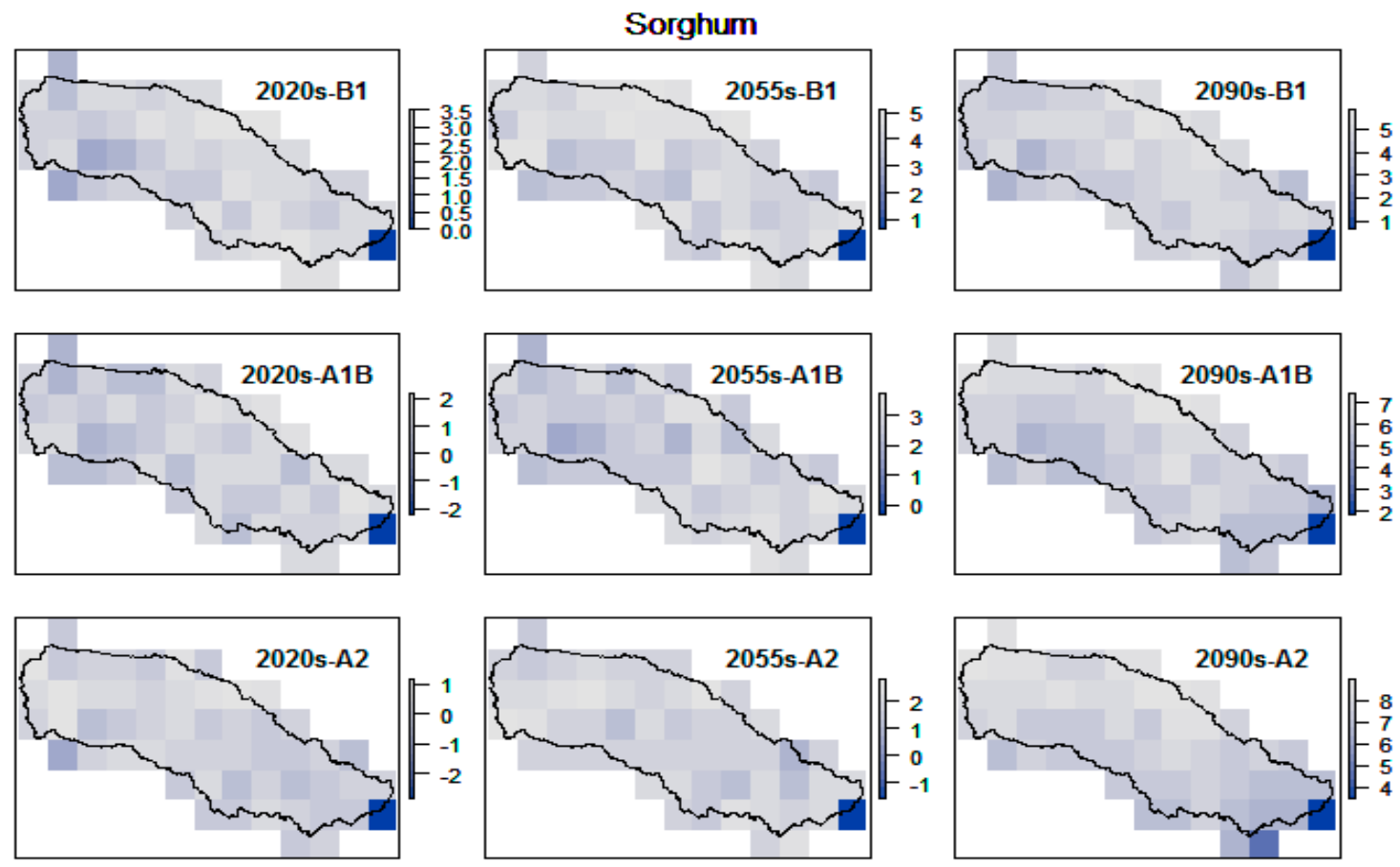

(c)

Figure 6. Cont. 


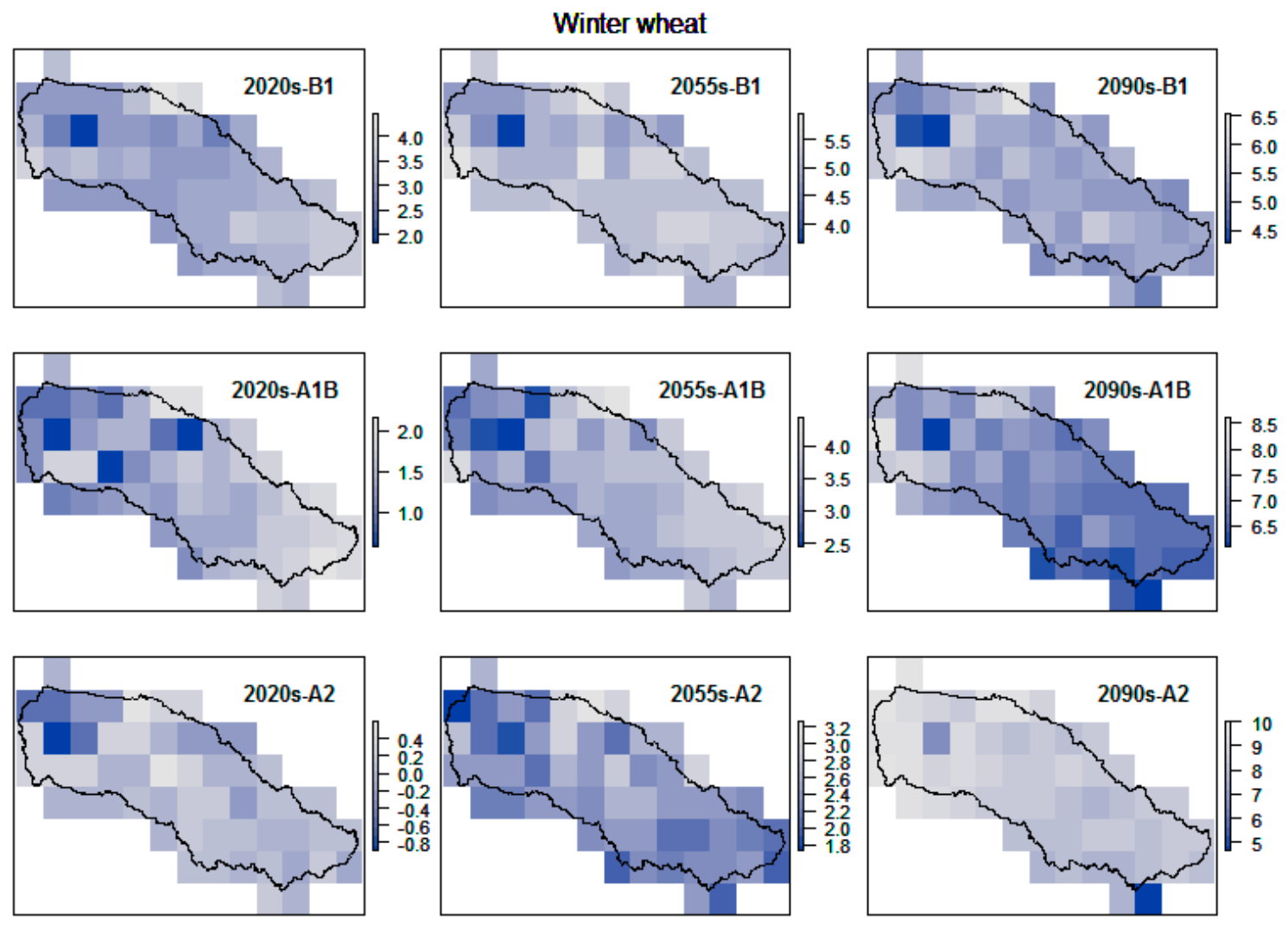

(d)

Figure 6. Spatial changes (in percentage) of irrigation requirement of corn (a); cotton (b); sorghum (c); and winter wheat (d) for three future periods (2020s, 2055s, and 2090s) and under three greenhouse emission scenarios compared with the baseline period.

In general, predicted changes in IRR of all crops for the three future periods under the studied scenarios were within the same order of magnitude despite apparent differences in length of the cropping session, with winter wheat having a cropping season almost twice that of the other three crops. Of the four crops, significant increases in IRR are predicted for sorghum and winter wheat during the 2090s period under the A2 (high) emission scenario. Overall, there was no consistent spatial trend in changes of IRR for the four crops across the Brazos Headwaters Basin.

\subsection{Effects of Changes in Precipitation on Irrigation Requirement}

Projected effects of changes in precipitation are negatively correlated with change in IRR (Figure 7). Projected increases in precipitation are expected to results in a reduction of IRR. However, this is not a one-to-one relation between changes in precipitation and IRR (Figure 7). In addition, while the effects of changes in precipitation show similar trends for all crops, the magnitude of this relationship was crop specific. This indicates that a unit change in precipitation is projected to affect IRR differently depending on the crop type. Figure 7 shows that the effect of precipitation was more pronounced on corn followed by cotton, while IRR of winter wheat was least affected by precipitation change among the four crops studied. Fares et al. [5] reported that future change in precipitation on citrus irrigation requirements is not constant across climatic regions; the effect of precipitation was more pronounced in humid climates than in arid climates. However, under certain conditions, several authors reported that the effects of decrease in precipitation on IRR would be masked by the effect of $\mathrm{CO}_{2}$ on crop evapotranspiration $[5,13,28,32]$. 


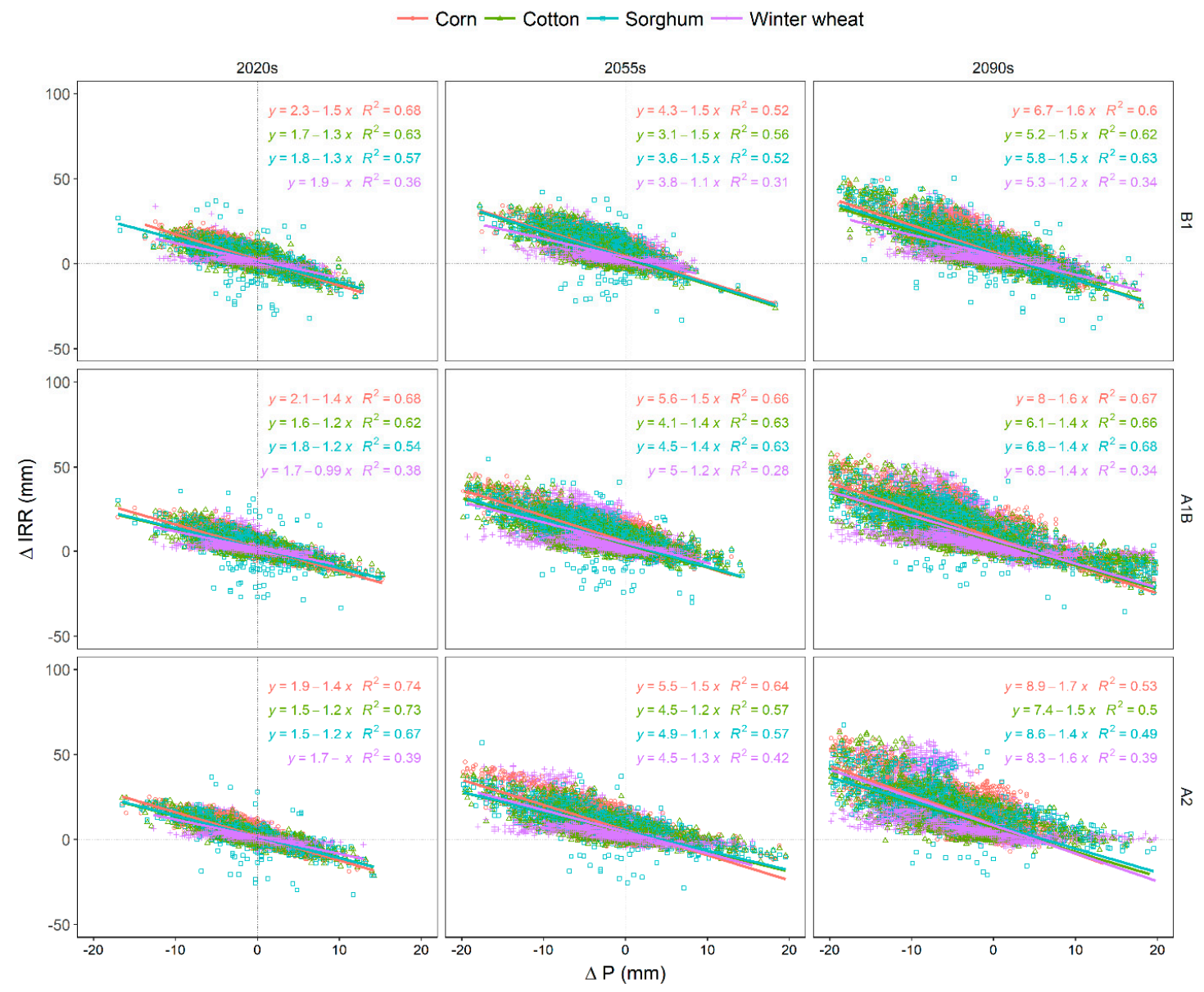

Figure 7. Effects of changes in precipitation on crop irrigation requirements of corn, cotton, sorghum, and winter wheat in the Brazos Headwaters Basin.

\section{Conclusions}

Potential climate change impacts on irrigation water requirements of four major crops (cotton, corn, sorghum, and winter wheat) grown in the Brazos Headwaters Basin, Texas were assessed for the baseline (1980-2010) and three future periods 2020s, 2055s, and 2090s using outputs of 15 GCMs under three GHG emission scenarios. Irrigation water requirements and other water budget components were calculated, for all four crops at 55 grids in the study area, using the IManSys model.

On average, precipitation meets only $25-32 \%$ of the evapotranspiration demand, depending on crop type. Drainage water losses were relatively small compared with other water budget components. Projected changes in the major water budget components show that evapotranspiration and IRR will increase for all crops, while precipitation is projected to decrease compared with the baseline period.

In general, almost all GCMs project an increase in IRR for all crops for the three future periods under the three greenhouse gas emission scenarios. Irrigation requirement prediction variability between GCMs was consistently greater during July and August for corn, cotton, and sorghum during all future periods and emission scenarios. However, for winter wheat, greater variability in GCMs' predictions were observed during April and May.

Irrigation requirements show significant spatial variability. Overall, IRR of all four crops is expected to increase throughout the Brazos Headwaters Basin under the three emission scenarios and for the three future periods, except in few cases for sorghum and winter wheat. There was no consistent spatial trend in changes of IRR for the four crops. 
Effects of changes in precipitation on IRR showed similar trends for all crops; however, the magnitude of the change varied with crops. This indicates that a unit change in precipitation is projected to affect IRR differently depending on the crop type.

Further study on estimating projected crop yield using crop models and evaluating different adaptation measures, e.g., shifting sowing date, variable rate irrigation, and use of cultivars with longer/shorter cropping seasons, will help in identifying alternative options for adapting climate change in the Brazos Headwaters Basin.

Author Contributions: R.A. and A.F. contributed in formulating the research question and guiding students to prepare data and simulation. R.A., H.B., and A.F. analyzed data and prepared the original manuscript. All authors contributed in addressing reviewers comments during the review process and proofreading of the accepted manuscript.

Funding: This research was funded by USDA National Institute of Food and Agriculture, Evans-Allen project, and Texas A\&M AgriLife Research.

Acknowledgments: This work was supported by the USDA National Institute of Food and Agriculture, Evans-Allen project, and Texas A\&M AgriLife Research. The authors wish to thank Yassine Cherif and Malik Mohammad for their assistance in data preparation and simulation.

Conflicts of Interest: The authors declare no conflict of interest.

\section{References}

1. Adams, R.M.; Rosenzweig, C.; Peart, R.; Ritchie, J.T.; McCarl, B.A.; Glyer, J.D.; Curry, R.B.; Jones, J.W.; Boote, K.J.; Allen, L.H. Global climate change and US agriculture. Nature 1990, 345, 219-224. [CrossRef]

2. Arnell, N.W. Climate change and global water resources. Glob. Environ. Chang. 1999, 9, S31-S49. [CrossRef]

3. Awal, R.; Bayabil, H.; Fares, A. Analysis of Potential Future Climate and Climate Extremes in the Brazos Headwaters Basin, Texas. Water 2016, 8, 603. [CrossRef]

4. Blanc, E.; Caron, J.; Fant, C.; Monier, E. Is current irrigation sustainable in the United States? An integrated assessment of climate change impact on water resources and irrigated crop yields: Climate change impact on irrigated crops. Earths Future 2017, 5, 877-892. [CrossRef] [PubMed]

5. Fares, A.; Bayabil, H.; Zekri, M.; de Mattos, D.; Awal, R. Potential climate change impacts on citrus water requirement across major producing areas in the world. J. Water Clim. Chang. 2017, 8, 576-592. [CrossRef]

6. Arnell, N.W. Climate change and global water resources: SRES emissions and socio-economic scenarios. Glob. Environ. Change 2004, 14, 31-52. [CrossRef]

7. Medany, M. Impact of Climate Change on Arab Countries. In Arab Environment: Future Challenges; Tolba, M.K., Saab, N.W., Eds.; Arab Forum for Environment and Development (AFED): Berirut, Lelanon, 2008; pp. 128-136.

8. Vogl, A.L.; Lopes, V.L. Impacts of water resources development on flow regimes in the Brazos River. Environ. Monit. Assess. 2009, 157, 331-345. [CrossRef] [PubMed]

9. Anderson, K.A.; Beitinger, T.L.; Zimmerman, E.G. Forage fish assemblages in the Brazos River upstream and downstream from Possum Kingdom Reservoir, Texas. J. Freshw. Ecol. 1983, 2, 81-88. [CrossRef]

10. Connor, J.; Schwabe, K.; King, D. Irrigation to meet growing food demand with climate change, salinity and water trade. WIT Trans. Ecol. Environ. 2008, 112, 43-52.

11. Safeeq, M.; Fares, A. Hydrologic response of a Hawaiian watershed to future climate change scenarios. Hydrol. Process. 2012, 26, 2745-2764. [CrossRef]

12. Farber, D.A. Modeling climate change and its impacts: Law, policy, and science. Tex. L. Rev. 2007, 86, 1655.

13. Fares, A.; Awal, R.; Fares, S.; Johnson, A.B.; Valenzuela, H. Irrigation water requirements for seed corn and coffee under potential climate change scenarios. J. Water Clim. Chang. 2016, 7, 39-51. [CrossRef]

14. Baldys, S.; Schalla, F.E. Base Flow (1966-2009) and Streamflow Gain and Loss (2010) of the Brazos River from the New Mexico-Texas State line to Waco, Texas, 1st ed.; U.S. Geological Survey: Texas, NM, USA, 2012.

15. Semenov, M.A.; Barrow, E.M. LARS-WG: A Stochastic Weather Generator for Use in Climate Impact Studies: User Manual. 2002. Available online: http:/ / resources.rothamsted.ac.uk/sites/default/files/groups/masmodels/download/LARS-WG-Manual.pdf (accessed on 7 November 2018). 
16. Howell, T.A.; Evett, S.R.; Tolk, J.A.; Copeland, K.S.; Dusek, D.A.; Colaizzi, P.D. Crop coefficients developed at Bushland, Texas for corn, wheat, sorghum, soybean, cotton, and alfalfa. In Proceedings of the 2006 ASCE-EWRI World Water and Environmental Resources Congress, Omaha, NE, USA, 21-25 May 2006.

17. Allen, R.G.; Pereira, L.S.; Raes, D.; Smith, M. Crop Evapotranspiration: Guidelines for Computing Crop Water Requirements; Food and Agriculture Organization of the United Nations (FAO): Rome, Italy, 1998.

18. Borrelli, J.; Fedler, C.B.; Gregory, J.M. Mean Crop Consumptive Use and Free-Water Evaporation for Texas; Department of Civil Engineering Texas Tech University: Lubbock, TX, USA, 1998; p. 271.

19. Fares, A.; Fares, S. Irrigation Management System, IManSys, a User-Friendly Computer Based Water Management Software Package. In Proceedings of the Irrigation Show and Education Conference, Orlando, FL, USA, 2-6 November 2012.

20. El-Beltagy, A.; Madkour, M. Impact of climate change on arid lands agriculture. Agric. Food Secur. $2012,1,3$. [CrossRef]

21. Ragab, R.; Prudhomme, C. SW-Soil and water: Climate Change and Water Resources Management in Arid and Semi-arid Regions: Prospective and Challenges for the 21st Century. Biosyst. Eng. 2002, 81, 3-34. [CrossRef]

22. Sowers, J.; Vengosh, A.; Weinthal, E. Climate change, water resources, and the politics of adaptation in the Middle East and North Africa. Clim. Chang. 2001, 104, 599-627. [CrossRef]

23. Döll, P. Impact of climate change and variability on irrigation requirements: A global perspective. Clim. Chang. 2002, 54, 269-293. [CrossRef]

24. Hong, E.M.; Nam, W.H.; Choi, J.Y.; Pachepsky, Y.A. Projected irrigation requirements for upland crops using soil moisture model under climate change in South Korea. Agric. Water Manag. 2016, 165, 163-180. [CrossRef]

25. Borja, N.; Cho, J.; Choi, S.K. The influence of climate change on irrigation water requirements for corn in the coastal region of Ecuador. Paddy Water Environ. 2017, 15, 71-78. [CrossRef]

26. Hatch, U.; Jagtap, S.; Jones, J.; Lamb, M. Potential effects of climate change on agricultural water use in the Southeast U.S. J. Am. Water Resour. Assoc. 1999, 35, 1551-1561. [CrossRef]

27. Allen, R.G.; Gichuki, F.N.; Rosenzweig, C. $\mathrm{CO}_{2}$-induced climatic changes and irrigation water requirements. J. Water Resour. Plan. Manag. 1991, 117, 157-178. [CrossRef]

28. Konzmann, M.; Gerten, D.; Heinke, J. Climate impacts on global irrigation requirements under 19 GCMs, simulated with a vegetation and hydrology model. Hydrol. Sci. J. 2013, 58, 88-105. [CrossRef]

29. Elliott, J.; Deryng, D.; Müller, C.; Frieler, K.; Konzmann, M.; Gerten, D.; Glotter, M.; Flörke, M.; Wada, Y.; Best, N.; et al. Constraints and potentials of future irrigation water availability on agricultural production under climate change. Proc. Natl. Acad. Sci. USA 2014, 111, 3239-3244. [CrossRef] [PubMed]

30. Brumbelow, K.; Georgakakos, A.P. An assessment of irrigation needs and crop yield for the United States under potential climate changes. J. Geophys. Res. Atmos. 2001, 106, 27383-27405. [CrossRef]

31. Hopmans, J.W.; Hidalgo, H.G.; Detinger, M. Impact of Climate Change on Irrigation Water Availability, Crop Water Requirements and Soil Salinity in the SJV, CA; University of California: Oakland, CA, USA, 2008.

32. Lee, J.L.; Huang, W.C. Impact of Climate Change on the Irrigation Water Requirement in Northern Taiwan. Water 2014, 6, 3339-3361. [CrossRef]

(C) 2018 by the authors. Licensee MDPI, Basel, Switzerland. This article is an open access article distributed under the terms and conditions of the Creative Commons Attribution (CC BY) license (http://creativecommons.org/licenses/by/4.0/). 